\title{
Pengembangan multimedia pembelajaran matematika sebagai upaya mendukung proses pembelajaran blended learning
}

\author{
Ganda Yoga Swara *, Ambiyar Ambiyar, Fadhilah Fadhilah, Syahril Syahril \\ Universitas Negeri Padang. \\ J1. Prof. Dr. Hamka, Air Tawar Barat, Padang Utara, Padang, Sumatera Barat 25171, Indonesia. \\ gandayogaswara@gmail.com \\ * Corresponding Author
}

\section{ARTICLE INFO}

\section{Article History}

Received:

11 October 2020;

Revised:

14 October 2020;

Accepted:

2 December 2020

\section{Keywords}

Multimedia

pembelajaran;

Pembelajaran

matematika;

Blended learning;

Mathematics learning;

Mobile learning;

\begin{abstract}
Penelitian ini bertujuan untuk menghasilkan produk multimedia pembelajaran matematika untuk siswa Sekolah Dasar (SD) dan melihat sejauh mana produk multimedia tersebut dapat dimanfaatkan siswa dalam upaya mendukung proses blended learning. Penelitian ini dilaksanakan di SD Negeri 07 Kota Padang dengan menggunakan metode waterfall model. Waterfall model atau sering kali disebut sebagai classic life cycle adalah model pengembangan perangkat lunak yang menekankan fase-fase yang berurutan dan sistematis, dimulai dari analisis kebutuhan konsumen, dan berkembang melalui proses perencanaan (planning), implementasi (implementation), pengujian (testing), dan pemeliharaan (maintenance), yang berujung pada dukungan terus menerus untuk sebuah perangkat lunak yang utuh. Hasil penelitian menunjukkan bahwa produk multimedia yang dihasilkan adalah multimedia pembelajaran matematika untuk siswa sekolah dasar. Dapat disimpulkan bahwa aplikasi ini dapat menciptakan proses pembelajaran online yang efektif dan terintegrasi antara guru dengan siswa. Mempermudah siswa-siswi sekolah dasar dalam belajar matematika dimanapun dan kapanpun. Produk multimedia yang dihasilkan layak sebagai media pembelajaran berdasarkan hasil validasi oleh guru dan siswa, dengan hasil penilaian sangat baik.
\end{abstract}

This study aims to produce multimedia learning mathematics products for elementary school (SD) students and see the extent to which these multimedia products can be used by students in an effort to support the blended learning process. This research was conducted at SD Negeri 07 Padang City using the waterfall model method. Waterfall model or often referred to as the classic life cycle is a software development model that emphasizes sequential and systematic phases, starting from the specification of consumer needs and developing through the planning, modeling, construction, and development processes. deployment, which results in ongoing support for a complete piece of software. The results showed that the multimedia product produced was multimedia learning mathematics for elementary students. It can be concluded that this application can create an effective and integrated online learning process between teachers and students. Make it easier for elementary school students to learn mathematics anywhere and anytime. The resulting multimedia products are feasible as learning media based on the results of validation by teachers and students, with excellent assessment results.

This is an open access article under the CC-BY-SA license.

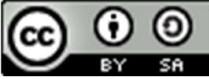




\section{PENDAHULUAN}

Pesatnya perkembangan zaman dan kemajuan teknologi memberi kemudahan bagi seseorang dalam mengemas dan menyajikan informasi, demikian pula dalam proses belajar mengajar. Penggunaan teknologi dan pemanfaatan media dalam pembelajaran dapat membangkitkan keinginan belajar, meningkatkan motivasi, merangsangan kegiatan belajar, dan mempengaruhi psikologis kepada siswa (Swara, 2020). Teknologi akan terus menjadi bagian dari aktifitas kelas dan alat bantu dalam kehidupan sehari-hari. Penggunaan teknologi dan informasi dapat membantu manusia dalam berkomunikasi, praktek berketerampilan hidup, dan dapat lebih memahami konsep. Salah satu produk teknologi yang dapat digunakan sebagai inovasi dalam pembelajaran adalah multimedia pembelajaran (Anisya \& Swara, 2020).

Dunia pendidikan saat ini dituntut untuk dikembangkanya pendekatan pembelajaran. Hal ini seiring dengan perkembangan psikologi peserta didik, dinamika sosial, serta dinamika sistem pendidikan pada setiap negara yang terus berubah. Sekolah Dasar (SD) merupakan jenjang awal untuk menanamkan konsep dasar pendidikan bagi anak, harapannya konsep-konsep yang diterima anak bisa sebagai pembuka daya pikinnya dalam menghadapi jenjang pendidikan berikutnya (Batubara, 2018). Pelaksanaan pembelajaran masalah di sekolah dasar tidaklah semudah yang diperkirakan. Ada banyak faktor yang menghambat terlaksananya pembelajaran pemecahan masalah secara optimal, tidak hanya faktor guru dan siswa saja saja, ada juga faktor tuntunan kurikulum yang membuat guru terdesak dengan waktu yang terbatas, sehingga tidak fokus terhadap kemampuan pemecahan masalah (Lidinillah, 2008).

Mata pelajaran matematika adalah salah satu mata pelajaran penting. Tujuan pembelajaran matematika di sekolah menurut Peraturan Kementerian Pendidikan Nasional Republik Indonesia No. 22 tahun 2006 meliputi: 1.) Memahami konsep matematika, menjelaskan keterkaitan antar konsep dan mengaplikasikan konsep atau algoritma secara luas, akurat, efisien, dan tepat dalam pemecahan masalah; 2.) Menggunakan pemahaman pada pola dan sifat, melakukan manipulasi matematika dalam membuat generalisasi, menyusun bukti, atau menjelaskan gagasan dan pernyataan matematika; 3.) Memecahkan masalah yang meliputi kemampuan memahami masalah, merancang model matematika, menyelesaikan model, dan menafsirkan solusi yang diperoleh; 4.) Mengkomunikasikan gagasan dengan simbol, tabel, diagram, atau media lain untuk memperjelas keadaan atau masalah; dan 5) Memiliki sikap menghargai kegunaan matematika dalam kehidupan, yaitu memiliki rasa ingin tahu, perhatian dan minat dalam mempelajari matematika, serta sikap ulet dan percaya diri dalam pemecahan masalah (Liana, 2009).

Selain itu, matematika juga termasuk mata pelajaran yang sulit untuk dipahami. Pemahaman konsep merupakan bagian yang paling penting dalam pembelajaran matematika (Zulkardi, 2003), artinya dalam mempelajari matematika peserta didik harus memahami konsep matematika terlebih dahulu agar dapat meyelesaikan soal-soal dan mampu mengaplikasikan pembelajaran tersebut di dunia nyata. Selain pemahaman konsep matematika siswa, kemandirian belajarpun merupakan komponen penting dalam pembelajaran matematika yang harus ditingkatkan. Kemandirian belajar tersebut turut menentukan keberhasilan peserta didik dalam belajar serta menunjukkan pengaruh positif terhadap pembelajaran dan pencapaian hasil belajar (Fatkhul, 2018). Rendahnya pemahaman siswa terhadap mata palajaran ini ditandai dengan adanya beberapa siswa yang mendapatkan nilai yang kurang memuaskan (Arifin \& Herman, 2018).

Dalam kegiatan pembelajaran, media memiliki peran yang penting yakni untuk menyampaikan materi pelajaran kepada pesera didik (Surahman \& Surjono, 2017). Media pembelajaran merupakan media informasi kegitan belajar mengajar sehingga mampu memberikan efektifitas dan interaktifitas dalam pembelajaran. Adanya media pada proses belajar mengajar, diharapkan dapat membantu guru dan siswa dalam pembelajaran lebih visual, interaktif, menarik, mudah, dan cepat dimengerti (Wibowo, 2013). Media pembelajaran merupakan alat yang dapat menyampaikan atau mengantarkan pesan-pesan pembelajaran (Amin, 2017). Penggunaan media pembelajaran yang menarik akan meningkatkan motivasi dan minat siswa untuk belajar yang pada akhirnya akan membuat siswa berhasil memahami materi yang diberikan (Setyadi, 2017). Degeng (2013) menjelaskan bahwa media pembelajaran adalah komponen strategi penyampaian yang dapat dimuati pesan yang akan disampaikan kepada peserta didik. Daryanto (2010) menjabarkan media 
pembelajaran memiliki kontribusi di antaranya adalah: 1.) Penyampaian pesan pembelajaran dapat lebih terstandar; 2.) Pembelajaran dapat lebih menarik; 3.) Pembelajaran menjadi lebih interaktif dengan menerapkan teori belajar; 4.) Waktu pelaksanaan pembelajaran dapat diperpendek; 5.) Kualitas pembelajaran dapat ditingkatkan; 6.) Proses pembelajaran dapat berlangsung kapanpun dan dimanapun diperlukan; 7.) Sikap positif peserta didik terhadap materi pembelajaran serta proses pembelajaran dapat ditingkatkan; dan 8.) Peran guru mengalami perubahan kearah yang positif.

Melihat potensi ini, pengembangan media pembelajaran dengan memanfaatkan telepon seluler adalah dengan membuat mobile learning yang ditujukan untuk semua telepon seluler berplatform Android. Alasannya karena operating system Android menjelma menjadi sebuah sistem yang paling banyak digunakan pada smartphone. Kemunculan smartphone dan Android bertujuan memberikan kemudahan untuk mengakses segala informasi yang dibutuhkan oleh user yang dapat diakses dimana saja dan kapan saja, akan tetapi dengan kecanggihan yang dimiliki keduanya, masyarakat hanya menggunakan smartphone dan android untuk mengakses media sosial (Firdaus \& Hamdu, 2020). Hal tersebut diperkuat berdasarkan hasil riset yang dilakukan oleh Wibisono (2014) dari Asosiasi Penyelenggara Jasa Internet Indonesia yang menemukan bahwa pengguna internet di Indonesia masih belum serius memanfaatkan kekuatan teknologi untuk kegiatan produktif (Ambiyar \& Arif, 2018).

Android adalah sistem operasi berbasis Linux yang diperuntukkan untuk mobile device (Wahyuningsih \& Budiningsih, 2014). Android merupakan sistem operasi yang paling diminati di masyarakat karena memiliki kelebihan seperti sifat open source yang memberikan kebebasan para pengembang untuk menciptakan aplikasi (Nuryadi, 2019). Dikembangkan bahan ajar mobile learning dirasa perlu dalam upaya membantu para siswa untuk memahami konsep dan meningkatkan kemandirian belajar siswa. Media pembelajaran berbasis teknologi yang lazim digunakan adalah komputer (Akhmadan, 2017). Peran media sangat penting dalam proses pembelajaran agar materi yang disampaikan oleh guru cepat sampai dan mudah diterima secara maksimal oleh siswa (Wicaksono, 2016). Beberapa penelitian dan pengembangan sebelumnya yang dinilai layak dan efektif digunakan sebagai media pembelajaran, diantranya adalah pengembangan multimedia pembelajaran interaktif dengan macromedia flash (Maskur, Nofrizal, \& Syazali, 2017).

Apakah efektif dan bermanfaat apabila mata pelajaran matematika menggunakan mobile learning dalam upaya meningkatkan hasil dan mendukung program blanded learning dalam kondisi pandemi seperti ini? Agar dapat mencapai tujuan tersebut maka perlu adanya inovasi baik dari model pembelajaran, metode, dan media yang diterapkan dalam proses pembelajaran yang tentu saja diusahakan sesuai dengan tingkat pendidikan siswa serta yang relevan dengan karakteristik siswa tersebut. Ketepatan dalam memilih model, metode, dan media sangat besar pengaruhnya bagi siswa dalam upaya memahami konsep-konsep pembelajaran matematika (Fadhilah, Effendi, \& Ridwan, 2017). Penyajian pembelajaran yang dilakukan dengan menghadirkan teks disertai gambar, video tentang beberapa analisis dampak terhadap suatu pembelajaran online membuat siswa menjadi lebih semangat (Alwan, 2017). Wulandari, Susilo, dan Kuswandi (2017) menyebutkan bahwa mobile learning sangat membutuhkan media yang menerapkan teknologi untuk menjalin komunikasi antara guru dan peserta didik. Mobile learning adalah pembelajaran yang dikemas melalui perangkat bergerak (mobile device). Mobile learning memudahkan para peserta didik untuk belajar kapan saja dan di mana saja. Dengan adanya aplikasi mobile untuk pelajaran matematika ini diharapkan dapat membantu para siswa dalam memahami pelajaran matematika (Koesnandar, 2019). Penggunaan mobile learning dalam pembelajaran matematika memiliki beberapa keunggulan, diantaranya: 1.) Mobile learning dapat dioperasikan dimanapun dan kapanpun; 2.) Meningkatkan motivasi siswa; dan 3.) Meningkatkan pembelajaran sesuai kebutuhan siswa (Saputra, 2015).

Tujuan dari penelitian ini adalah mengembangkan multimedia pembelajaran matematika untuk siswa Sekolah Dasar (SD) dan melihat sejauh mana produk multimedia tersebut dapat dimanfaatkan siswa dalam upaya mendukung proses blended learning. Blended learning berasal dari kata blended dan learning. Blended membawa maksud campuran dan learning bermaksud belajar. Dari kedua unsur kata tersebut dapat diketahui bahwa konsep blended learning ini merupakan percampuran pola belajar. Pola belajar yang dicampurkan adalah dua unsur utama yaitu pembelajaran di kelas dengan online learning (Ahmad, 2017). Penelitian dan pengembangan yang dilakukan untuk mengetahui respon siswa terhadap pengembangan media pembelajaran matematika dengan mobile 
108 - Jurnal Inovasi Teknologi Pendidikan

learning. Selain materi belajar, pada pengembangan ini diberi beberapa animasi dan games sebagai rangsangan motivasi belajar siswa.

\section{METODE}

Penelitian ini merupakan suatu penelitian yang bersifat eksperimen, yaitu merancang sebuah sistem aplikasi matematika learning untuk sekolah dasar pada smartphone berbasis sistem operasi Android menggunakan bahasa pemrograman java. Penelitian dilaksanakan pada bulan Januari sampai dengan April 2019. Sumber data yang akan diolah adalah berasal dari siswa-siswi dan guru SD Negeri 07 Kota Padang. Proses pengujian aplikasi dilakukan dengan pengisian kuisioner oleh pengguna dengan menggunakan skala linkert dan diolah dengan bantuan program aplikasi untuk analisis statistik dan manajemen data yaitu SPSS. Instrumen penelitian pada penelitian ini adalah antara lain dengan studi pustaka yang dilakukan dengan mempelajari beberapa buku literature atau artikel yang berhubungan dengan penelitian ini. Selanjutnya yaitu wawancara dengan cara melakukan tanya jawab dengan pihak terkait yaitu guru dan siswa, pihak guru dan siswa menjelaskan proses atau kondisi pembelajaran saat ini terutama pada proses pembelajaran matematika. Terakhir yaitu observasi melalui jurnal-jurnal yang berkaitan dengan blended learning untuk mendapatkan gambaran mengenai aplikasi dan informasi lainnya yang mendukung penelitian.

Menurut Kramer (2018) waterfall model adalah suatu jenis penelitian yang menekankan kepada proses untuk menghasilkan atau mengembangkan dan memvalidasi sebuah produk. Metode waterfall merupakan model pengembangan sistem informasi yang sistematik dan sekuensial (Sasmito, 2017). Proses dari metode waterfall yaitu: 1.) Analisis kebutuhan; 2.) Proses perencanaan (planning); 3.) Implementasi (implementation); 4.) Pengujian (testing); dan 5.) Pemeliharaan (maintenance). Pertama spesifikasi kebutuhan konsumen adalah layanan sistem, kendala, dan tujuan ditetapkan oleh hasil konsultasi dengan pengguna yang kemudian didefinisikan secara rinci dan berfungsi sebagai spesifikasi sistem. Analisis kebutuhan yang diperlukan untuk menentukan kemampuan-kemampuan atau kompetensi yang perlu dipelajari oleh siswa untuk meningkatkan prestasi belajar. Kedua, proses perencanaan (planning). Tahapan perancangan sistem dilakukan dengan mengalokasikan kebutuhan-kebutuhan sistem baik perangkat keras (hardware) maupun perangkat lunak (software) dengan membentuk arsitektur sistem secara keseluruhan. Perancangan perangkat lunak melibatkan identifikasi dan penggambaran abstraksi sistem dasar perangkat lunak dan hubungannya. Pada langkah perencanaan (planning) diperlukan adanya klarifikasi program pembelajaran yang didesain, sehingga program tersebut dapat mencapai tujuan pembelajaran seperti yang diharapkan. Pada tahap ini dilakukan 3 langkah, yaitu: 1.) Membuat usecase diagram; 2,) Membuat class diagram; dan 3.) Membuat activity diagram (Purnamasari \& Herman, 2016).

Ketiga, implementasi (implementation). Pada tahap implementasi, perancangan perangkat lunak direalisasikan sebagai serangkaian program atau unit program. Pengujian melibatkan verifikasi bahwa setiap unit memenuhi spesifikasinya. Secara khusus Pada tahapan ini dilakukan pembuatan aplikasi multimedia pembelajaran. Keempat, tahap pengujian (testing) untuk mendapatkan masukan dari guru dan siswa. Unit-unit individu program atau program digabung dan diuji sebagai sebuah sistem lengkap untuk memastikan apakah sesuai dengan kebutuhan perangkat lunak atau tidak. Setelah pengujian, perangkat lunak dapat dipergunakan oleh konsumen. Kelima, tahap pemeliharaan (maintenance), yang berujung pada dukungan terus menerus untuk sebuah perangkat lunak yang utuh. Tahapan ini merupakan tahapan yang paling panjang. Sistem dipasang dan digunakan secara nyata. Maintenance melibatkan pembetulan kesalahan yang tidak ditemukan pada tahapan-tahapan sebelumnya, meningkatkan implementasi dari unit sistem, dan meningkatkan layanan sistem sebagai kebutuhan baru.

\section{HASIL DAN PEMBAHASAN}

Berdasarkan metode yang digunakan dalam penelitian ini, maka dilakukan dalam lima tahap, Pertama spesifikasi kebutuhan konsumen, dalam mencari informasi mengenai kebutuhan konsumen, penelitian dapat berangkat dari adanya potensi atau masalah. Pada tahapan ini, didasari dengan adanya suatu potensi masalah bahwa ditemukan minimnya penggunaan media pembelajaran dalam 
pembelajaran matematika. Peneliti melakukan observasi dengan menyebarkan angket, referensi dari beberapa jurnal dan wawancara dengan guru dan siswa. Kedua, Proses perencanaan (planning). Pada tahap ini, perencanaan dibuat dengan Unifield Modeling Language atau yang selanjutnya disebut UML. UML merupakan salah satu metode pemodelan visual yang digunakan dalam perancangan dan pembuatan sebuah software yang berorientasikan pada objek. UML merupakan sebuah standar penulisan atau semacam blueprint dimana didalamnya termasuk sebuah bisnis proses, penulisan kelas-kelas dalam sebuah bahasa yang spesifik (Prihandoyo, 2018).

Pada tahap kedua ini dilakukan 3 langkah, yaitu: 1.) Membuat usecase diagram; 2.) Membuat class diagram; dan 3.) Membuat activity diagram. Usecase diagram merupakan gambaran dari fungsionalitas yang diharapkan dari sebuah sistem, dan merepresentasikan sebuah interaksi antara actor dan sistem. Didalam usecase terdapat actor yang merupakan sebuah gambaran entitas dari manusia atau sebuah sistem yang melakukan pekerjaan di sistem. Usecase menjelaskan proses yang bisa dilakukan actor dengan menu relasi sebagai penunjuknya. Dalam menu utama ada materi, mengerjakan soal, bantuan, dan tentang aplikasi (Nasution, 2016). Usecase diagram dalam pengembangan pada penelitian ini dapat dilihat pada Gambar 1.

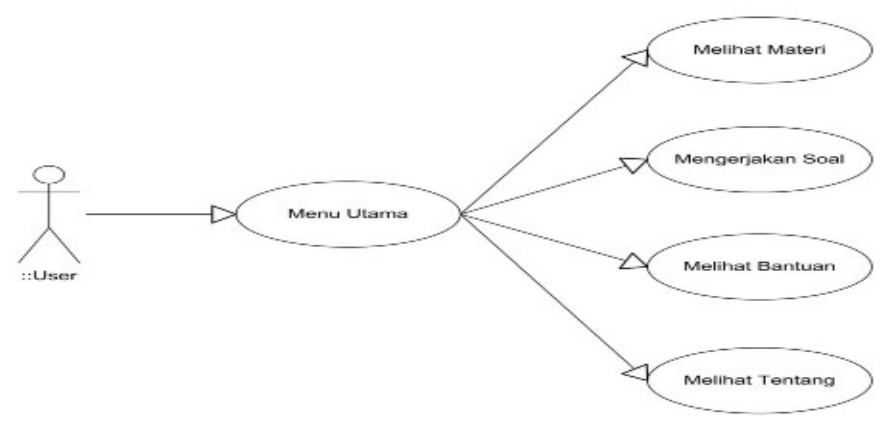

Gambar 1. Usecase Diagram

Class diagram merupakan gambaran dari struktur sistem dari segi pendefinisian kelas-kelas yang akan dibuat untuk membangun sistem (Abidin, Purnama, \& Nugroho, 2013). Class diagram terdiri dari atribut dan operasi dengan tujuan pembuat pembuat program dapat membuat hubungan antara dokumentasi perancangan dan perangkat lunak sesuai. Class Diagram merupakan gambaran struktur dan deskripsi dari class, package, dan objek yang saling berhubungan seperti diantaranya main activity, Bantuan, Tentang, Latihan Soal, Materi, Pilihan Jawaban, dan Hasil (Marfalino, Guslenda, \& Sari, 2017). Class diagram adalah hubungan antara satu class dengan class lainnya, dan atributnya dijelaskan dalam class diagram yang dapat dilihat pada Gambar 2. Seluruh perancangan yang dilakukan adalah menjadi acuan untuk mengimplementasikannya kedalam sebuah bahasa pemrograman.

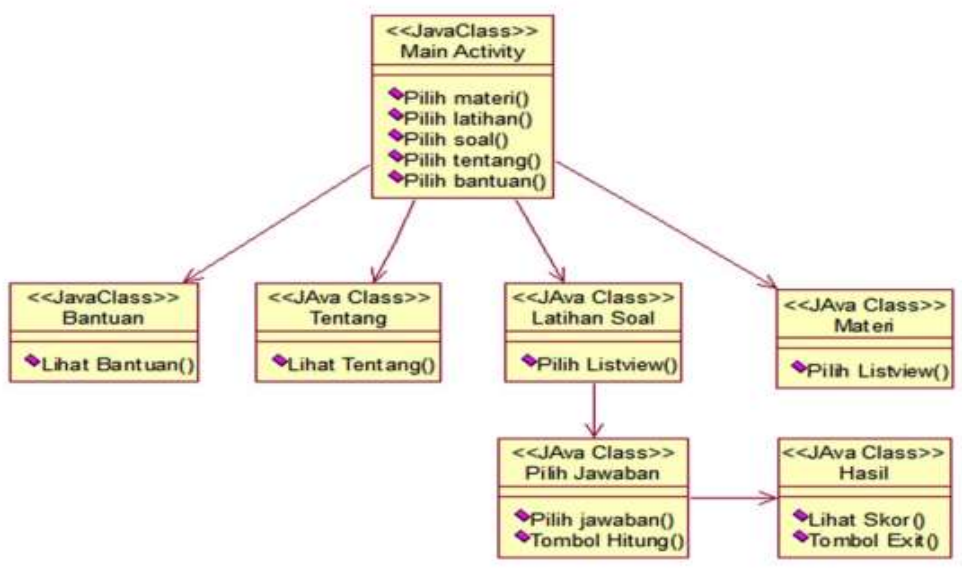




\section{Gambar 2. Class Diagram}

Activity diagram merupakan gambaran alir dari aktivitas-aktivitas didalam sistem yang berjalan. Activity diagram digunakan untuk menggambarkan urutan aktivitas proses bisnis (Marnita, Taufiq, Iskandar, \& Rahmi, 2020). Diagram aktivitas ditunjukkan pada Gambar 3 yang menjelaskan urutan aktifitas user terhadap sistem.

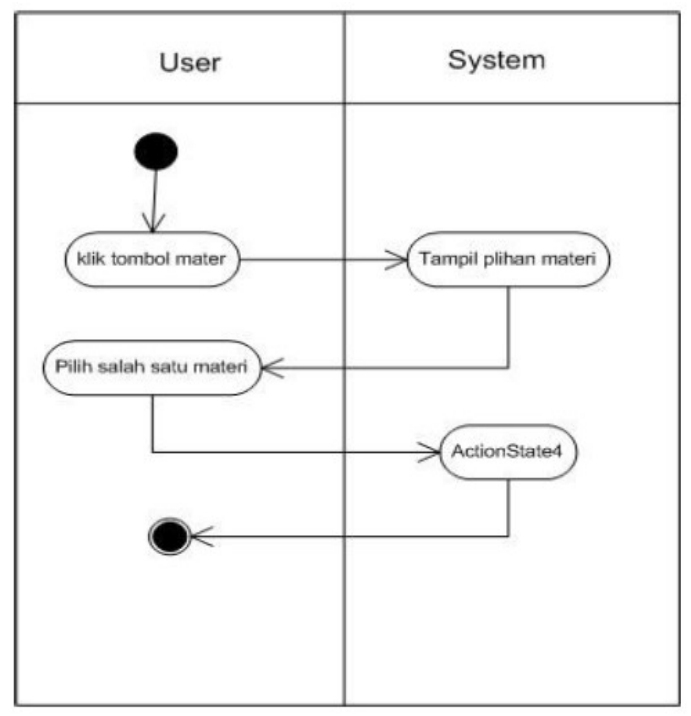

Gambar 3. Activity Diagram

Pada tahapan implementation dilakukan dengan membuat dan mengembangkan aplikasi multimedia pembelajaran sesuai dengan analisis kebutuhan dan proses perencanaan (planning) yang telah dilakukan. Perancangan antar muka dibuat untuk setiap tampilan layar yang berfungsi sebagai media komunikasi antara pengguna dengan sistem. Dengan adanya rancangan yang tepat akan menghasilkan sistem yang stabil dan mudah dikembangkan. Perancangan yang kurang baik akan mengakibatkan sistem yang akan dibangun tidak menghasilkan kinerja seperti yang diharapkan. Hasil implementasi multimedia pembelajaran dalam penelitian ini dapat dilihat pada Gambar 4.

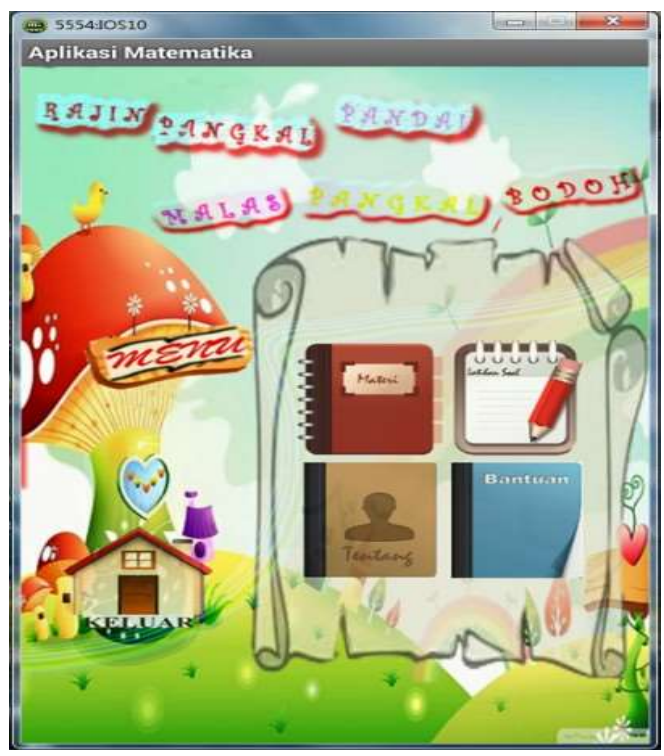

Gambar 4. Tampilan Halaman Utama 
Gambar 4 merupakan tampilan halaman utama pada aplikasi multimedia pembelajaran matematika. Pada halaman utama ini dirancang dengan warna dan tata letak yang tidak membosankan. Harapannya agar dapat mempengaruhi keinginan siswa dalam memulai dan mempelajari penggunaan aplikasi tersebut. Beberapa menu sudah disiapkan dan tersedia pada halaman utama ini diantaranya menu yang akan tampil yaitu siswa dapat melihat materi pelajaran matematika, melihat dan mencoba mengerjakan soal-soal latihan, melihat bantuan, dan melihat informasi tentang aplikasi tersebut. Menu bantuan berisi tentang bagaimana cara penggunaan aplikasi multimedia pembelajaran ini, sedangkan untuk menu tentang yaitu berisi informasi-informasi mengenai pihak penyedia atau pengembang dari aplikasi multimedia pembelajaran.

Selanjutnya, pada halaman antar muka materi menampilkan materi-materi apa saja yang dibahas pada aplikasi multimedia yang dikembangkan. Terdapat beberapa menu untuk pembahasan materi mengenai bangun datar, bangun ruang, bilangan pecahan, operasi bilangan pecahan, satuan ukuran, rumus bangun datar, rumus bangun ruang, skala, dan pengolahan data. Tampilan halaman materi dapat dilihat pada Gambar 5.

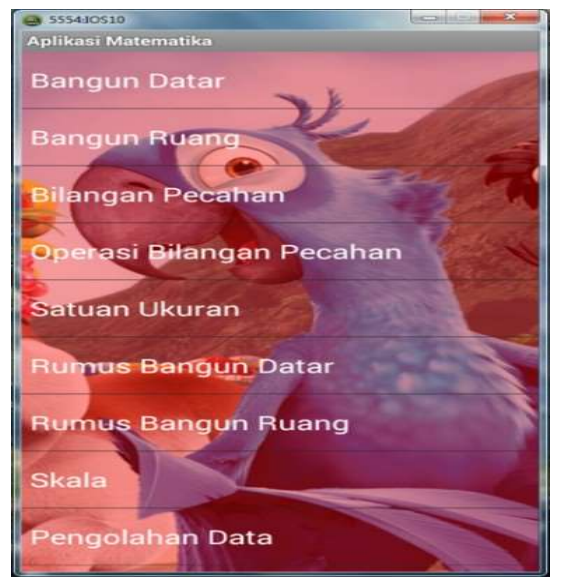

Gambar 5. Tampilan Halaman Materi

Selanjutnya apabila siswa menekan tombol salah satu listview pada halaman materi, maka akan menampilkan informasi yang sangat lengkap mengenai materi tersebut dan dilengkapi gambar bergerak (animasi). Rancangan tampilan halaman informasi materi ini dapat dilihat pada gambar 6 . Sebagai contoh ketika siswa memilih untuk membuka menu materi bangun datar. Pada menu ini terdapat banyak informasi mengenai bangun datar seperti macam-macam bangun datar, pengertiannya, serta rumus-rumusnya.

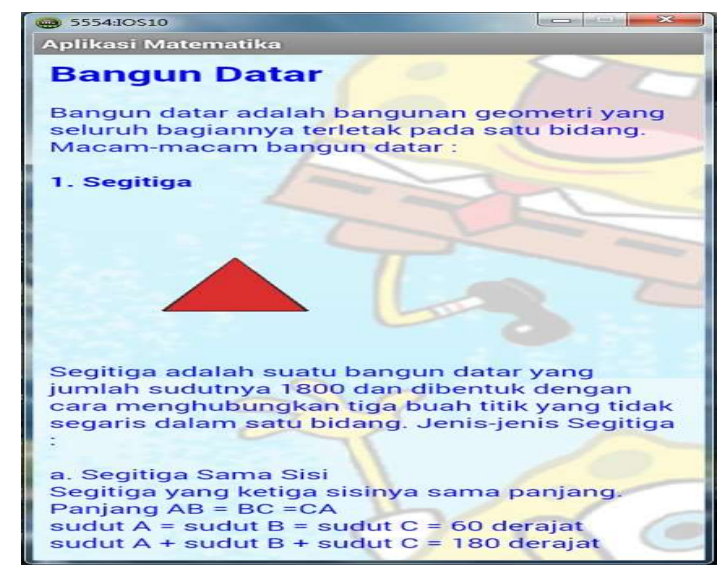

Gambar 6. Tampilan Halaman Materi 
Selanjutnya, pada menu latihan atau evaluasi hasil pembelajaran akan menampilkan soalsoal latihan yang berkaitan dengan semua materi yang disajikan dalam aplikasi multimedia pembelajaran ini. Soal-soal tersebut ditampilkan sebanyak 10 soal pada setiap satu kali latihan. Setiap latihan akan menampilkan pertanyaan atau soal-soal latihan yang berbeda-beda. Hal ini bisa dilakukan karena pada aplikasi multimedia ini jumlah soal tersimpan lebih banyak pada database. Pada menu latihan terdapat beberapa pilihan submenu yaitu bangun datar, bangun ruang, bilangan pecahan, operasi bilangan pecahan, satuan ukuran, skala, dan pengolahan data. Siswa bisa memilih jawaban yang benar sesuai dengan pilihan yang telah disediakan. Daftar pertanyaan dalam aplikasi multimedia pembelajaran ini dapat dilihat pada Gambar 7.

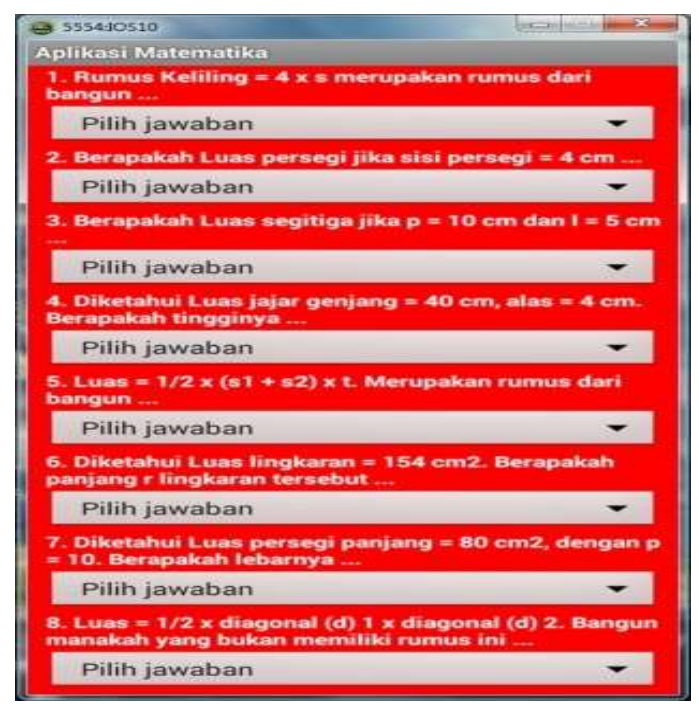

Gambar 7. Tampilan Halaman Latihan/Evaluasi

Setelah menjawab pertanyaan terakhir dari 10 soal yang ada, siswa selanjutnya dapat menekan tombol hitung untuk melihat jawaban yang benar dari soal-soal tersebut dan nilai yang diperoleh. Apabila ada jawaban siswa yang salah atau tidak sesuai dengan kunci jawaban yang tersimpan dalam database aplikasi multimedia pembelajaran tersebut, maka sistem otomatis akan memberi tahu jawaban yang benar untuk pertanyaan tersebut. Tampilan halaman skor dapat dilihat pada Gambar 8.

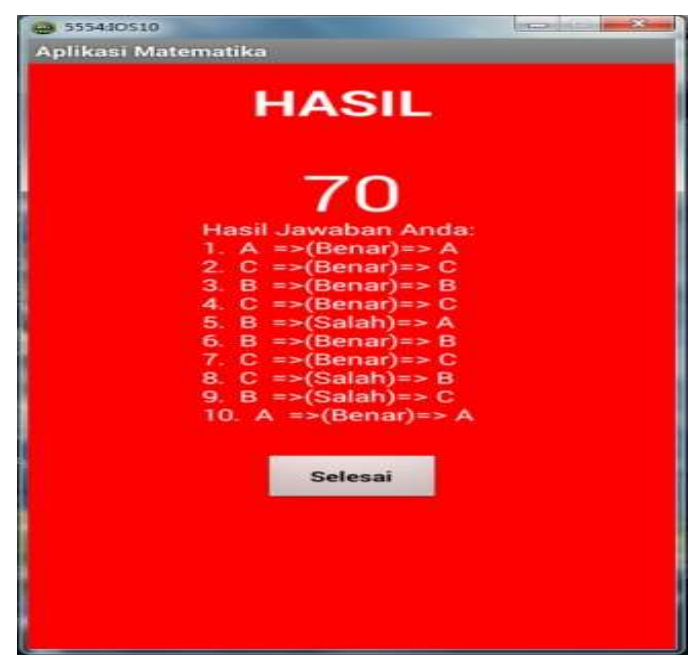

Gambar 8. Tampilan Halaman Skor 
Pada halaman antar muka bantuan ini menampilkan informasi singkat tentang bagaimana langkah-langkah untuk mengoperasikan aplikasi dan informasi apa saja yang terdapat dalam aplikasi tersebut. Tampilan halaman bantuan dapat dilihat pada Gambar 9.

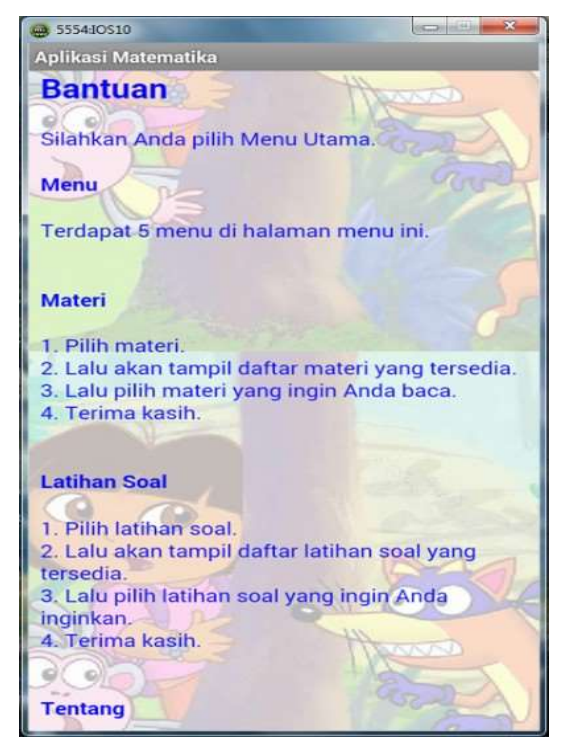

Gambar 9. Tampilan Halaman Bantuan

Pengujian aplikasi merupakan proses yang dilakukan untuk mengetahui apakah sistem sudah berjalan dengan benar dan tepat. Pengujian juga merupakan proses evaluasi untuk memastikan apakah aplikasi sudah siap digunakan atau belum. Pengujian dilakukan dengan cara pengisian kuesioner oleh pengguna, yaitu siswa dan guru dengan menggunakan skala likert (Wibawanto, 2017). Skala likert adalah suatu skala psikometrik yang digunakan dalam kuesioner dan merupakan salah satu teknik yang dapat digunakan dalam evaluasi suatu program atau kebijakan perencanaan (Sujarweni, 2019). Skala Likert mempunyai gradasi dari sangat positif sampai sangat negatif, yang dapat berupa kata-kata antara lain: Sangat setuju (SS) dengan nilai 5, setuju (S) dengan nilai 4, Netral / Ragu - ragu (RG) dengan nilai 3, Kurang setuju (KS) dengan nilai 2, Tidak setuju (TS) dengan nilai 1. Adapun pernyataan yang dibuat dalam penelitian ini dapat dilihat pada Tabel 1 .

Tabel 1. Pertanyaan Kuesioner

\begin{tabular}{cl}
\hline No. & \multicolumn{2}{c}{ Pertanyaan } \\
\hline 1. Apakah Aplikasi Matematika ini mudah untuk digunakan ? (X1) \\
2. Apakah Aplikasi Matematika ini bisa dijadikan alternatif / memudahkan untuk anda \\
belajar Metamatika? (X2) \\
4. Apakah Tampilan aplikasi Matematika ini sudah menarik? (X3) \\
4. Apakah Aplikasi Matematika ini menghilangkan rasa jenuh anda dalam belajar \\
5. Apakah Pembuatan aplikasi ini menjadikan anda lebih tertarik belajar Matematika? (X5) \\
6. Apakah Setelah anda menggunakan aplikasi ini, anda merasa ingin menggunakannya lagi? \\
7. Apakah Aplikasi ini lebih mudah digunakan daripada buku paket? (X7) \\
8. Apakah Belajar dengan aplikasi ini lebih anda sukai dibandingkan dengan buku paket? (X8) \\
9. Apakah Aplikasi ini berjalan baik tanpa error di smartphone android anda ? (X9) \\
10. Apakah setelah menggunakan aplikasi ini, anda dapat mengerjakan soal-soal yang ada \\
\hline
\end{tabular}

Langkah berikutnya setelah responden mengisi kuisioner yang diberikan, maka data kuisioner tersebut diolah dengan menggunakan aplikasi pengolahan statistik dan manajemen data 
SPSS. Gambar 10 adalah tampilan awal data kuesioner yang akan diolah di SPSS dapat dilihat pada Gambar 10. Setelah data kuesioner tersebut diolah dengan menggunakan SPSS, diperoleh data ahsil perhitungan seperti yang dapat dilihat pada Gambar 11 .

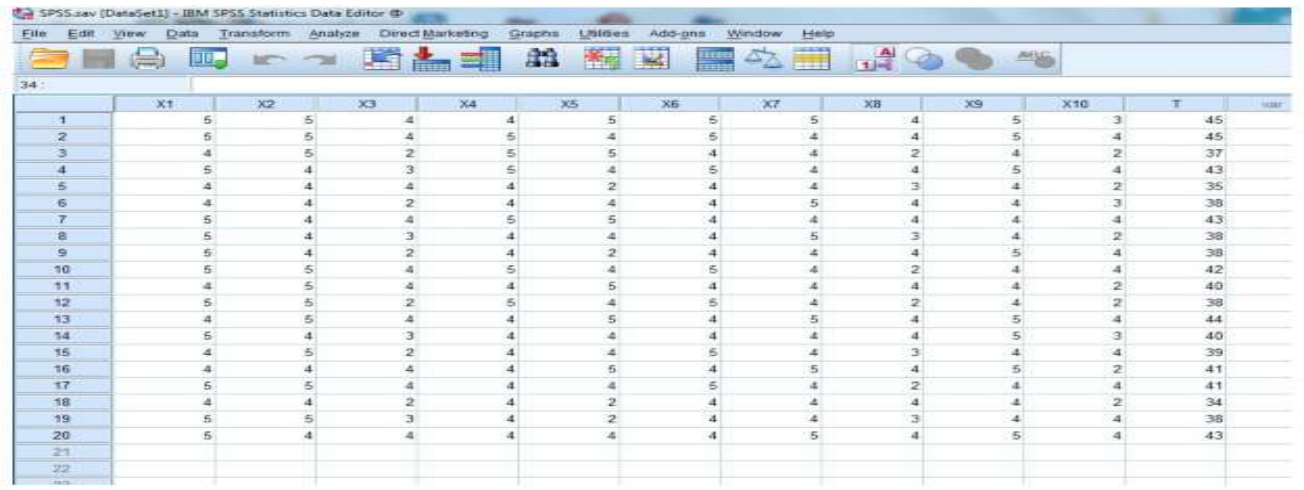

Gambar 10. Tampilan Pengolahan Data dengan Menggunakan SPSS

\begin{tabular}{|l|r|r|r|r|r|r|r|r|r|}
\hline & \multicolumn{1}{|c|}{$\mathrm{N}$} & \multicolumn{1}{c|}{ Range } & \multicolumn{1}{c|}{ Minimum } & \multicolumn{1}{c|}{ Maximum } & \multicolumn{1}{c|}{ Sum } & \multicolumn{2}{|c|}{ Mean } & Std. Deviation & Variance \\
\cline { 2 - 9 } & Statistic & Statistic & Statistic & \multicolumn{1}{c|}{ Statistic } & Statistic & Statistic & Std. Error & Statistic & Statistic \\
\hline X1 & 20 & 1 & 4 & 5 & 92 & 4,60 &, 112 &, 503 &, 253 \\
X2 & 20 & 1 & 4 & 5 & 90 & 4,50 &, 115 &, 513 &, 263 \\
X3 & 20 & 2 & 2 & 4 & 64 & 3,20 &, 200 &, 894 &, 800 \\
X4 & 20 & 1 & 4 & 5 & 86 & 4,30 &, 105 &, 470 &, 221 \\
X5 & 20 & 3 & 2 & 5 & 78 & 3,90 &, 240 & 1,071 & 1,147 \\
X6 & 20 & 1 & 4 & 5 & 87 & 4,35 &, 109 &, 489 &, 239 \\
X7 & 20 & 1 & 4 & 5 & 86 & 4,30 &, 105 &, 470 &, 221 \\
X8 & 20 & 2 & 2 & 4 & 68 & 3,40 &, 184 &, 821 &, 674 \\
X9 & 20 & 1 & 4 & 5 & 88 & 4,40 &, 112 &, 503 &, 253 \\
X10 & 20 & 2 & 2 & 4 & 63 & 3,15 &, 209 &, 933 &, 871 \\
T & 20 & 11 & 34 & 45 & 802 & 40,10 &, 707 & 3,161 & 9,989 \\
Valid N & 20 & & & & & & & & \\
(listwise) & & & & & & & & & \\
\hline
\end{tabular}

Gambar 11. Tabel Hasil Descriptive Statistics

Descriptive Statistics adalah metode-metode yang berkaitan dengan pengumpulan dan penyajian suatu gugus data sehingga menaksir kualitas data berupa jenis variabel, ringkasan statistik (mean, median, modus, standar deviasi, dan lain sebagainya), distribusi, dan representasi bergambar (grafik), tanpa rumus probabilistik apapun (Adiwisastra, 2015). Nilai rata-rata dapat dilihat pada kolom mean, sedangkan nilai standar deviasi dapat dilihat pada std devation. Dengan cara tersebut, dapat diperoleh nilai rata-rata, minimum, maksimum, serta standar deviasi. Hasil perhitungan frequencies statistics dapat dilihat pada Gambar 12. Pada gambar 12 X1-X10 adalah pertanyaan kuesioner yang sejumlah 10 pertanyaan kepada responden. $\mathrm{N}$ menunjukkan jumlah responden yang mengisi kuesioner sejumlah 20 yang akan disebarkan kepada pelajar dan guru-guru. Nilai minimum menunjukan nilai terkecil yang akan dijawab oleh responden yaitu 2, sedangkan nilai maksimum menunjukan nilai terbesar yang akan dijawab oleh responden yaitu 5 .

Pada Gambar 12, X1 menjelaskan bahwa pada hasil pengujian dengan nilai rata-rata 4.60, nilai ini menunjukkan bahwa aplikasi ini mudah untuk digunakan. Hasil pengujian X2 dengan nilai rata-rata 4.50 , nilai ini menunjukan bahwa dengan adanya aplikasi ini dapat menjadi alternatif atau memberikan kemudahan kepada pengguna untuk belajar matematika. Hasil pengujian X3 dengan nilai rata-rata 3.20, nilai ini menunjukan bahwa pengguna setuju bahwa tampilan dari aplikasi ini sudah menarik. Hasil pengujian X4 dengan nilai rata-rata 4.30, nilai ini menunjukan bahwa aplikasi ini dapat menghilangkan rasa jenuh belajar pengguna dalam belajar matematika. Hasil pengujian X5 dengan nilai rata-rata 3.90, nilai ini menunjukan bahwa aplikasi ini membuat pengguna lebih tertarik dalam belajar matematika. Hasil pengujian X6 dengan nilai rata-rata 4.35, nilai ini menunjukan 
bahwa pengguna akan tetap menggunakan aplikasi ini lagi dalam belajar matematika. Hasil pengujian X7 dengan nilai rata-rata 4.30, nilai ini menunjukan bahwa aplikasi lebih mudah digunakan oleh pengguna dibandingkan dengan buku paket. Hasil pengujian X8 dengan nilai ratarata 3.40, nilai ini menunjukan bahwa pengguna menyukai belajar dengan aplikasi ini. Hasil pengujian X9 dengan nilai rata-rata 4.40, nilai ini menunjukan bahwa aplikasi ini berjalan dengan baik di smartphone para pengguna. Hasil pengujian X10 dengan nilai rata-rata 3.15 , nilai ini menunjukan bahwa dengan menggunakan aplikasi ini pengguna dapat mengerjakan soal latihan yang ada di dalam buku paket.

\begin{tabular}{|c|c|c|c|c|c|c|c|c|c|c|c|c|}
\hline & $\mathrm{X} 1$ & $\times 2$ & $x_{3}$ & $\mathrm{X} 4$ & $\times 5$ & $\mathrm{X} 6$ & $\mathrm{X7}$ & $\mathrm{x} 8$ & X9 & $\mathrm{x} 10$ & $T$ \\
\hline \multirow[t]{2}{*}{$\mathrm{N}$} & Valid & 20 & 20 & 20 & 20 & 20 & 20 & 20 & 20 & 20 & 20 & 20 \\
\hline & Missing & 0 & 0 & 0 & 0 & 0 & 0 & 0 & 0 & 0 & 0 & 0 \\
\hline \multicolumn{2}{|c|}{ Mean } & 4,60 & 4,50 & 3,20 & 4,30 & 3,90 & 4,35 & 4,30 & 3,40 & 4,40 & 3,15 & 40,10 \\
\hline \multicolumn{2}{|c|}{ Std. Error of Mean } & ,112 & ,115 & ,200 & 105 & ,240 & 109 & 105 & ,184 & 112 & ,209 & ,707 \\
\hline \multicolumn{2}{|c|}{ Median } & 5,00 & 4,50 & 3,50 & 4,00 & 4,00 & 4,00 & 4,00 & 4,00 & 4,00 & 3,50 & 40,00 \\
\hline \multicolumn{2}{|c|}{ Mode } & 5 & $4^{\mathrm{a}}$ & 4 & 4 & 4 & 4 & 4 & 4 & 4 & 4 & 38 \\
\hline \multicolumn{2}{|c|}{ Std. Deviation } &, 503 & .513 & 894 & .470 & 1,071 & ,489 & .470 & .821 &, 503 & 933 & 3,161 \\
\hline \multicolumn{2}{|c|}{ Variance } & ,253 & ,263 &, 800 & ,221 & 1,147 & ,239 & ,221 & ,674 &, 253 & ,871 & 9,989 \\
\hline \multicolumn{2}{|c|}{ Range } & 1 & 1 & 2 & 1 & 3 & 1 & 1 & 2 & 1 & 2 & 11 \\
\hline \multicolumn{2}{|c|}{ Minimum } & 4 & 4 & 2 & 4 & 2 & 4 & 4 & 2 & 4 & 2 & 34 \\
\hline \multicolumn{2}{|c|}{ Maximum } & 5 & 5 & 4 & 5 & 5 & 5 & 5 & 4 & 5 & 4 & 45 \\
\hline \multicolumn{2}{|c|}{ Sum } & 92 & 90 & 64 & 86 & 78 & 87 & 86 & 68 & 88 & 63 & 802 \\
\hline
\end{tabular}

Gambar 12. Hasil Frequencies Statistics

\section{SIMPULAN}

Berdasarkan hasil penelitian yang telah dilakukan dapat disimpulkan bahwa aplikasi multimedia pembelajaran matematika sebagai upaya dalam mendukung proses pembelajaran blended learning dapat menciptakan proses pembelajaran secara online yang efektif dan terintegrasi antara guru dengan siswa. Aplikasi ini dapat dengan mudah digunakan, dan memberikan kemudahan kepada siswa untuk belajar matematika. Mempermudah siswa-siswi sekolah dasar dalam belajar matematika dimanapun dan kapanpun. Selain itu aplikasi ini juga dapat mengakomodir kebutuhan terutama pada masa pandemi Covid-19. Dari hasil pengujian yang dilakukan dengan menggunakan SPSS menunjukkan bahwa aplikasi ini mudah untuk digunakan, dapat menjadi alternatif atau memberikan kemudahan kepada pengguna untuk belajar matematika, memiliki tampilan yang menarik, dapat menghilangkan rasa jenuh, dapat menarik perhatian siswa, mudah digunakan, dan dapat berjalan dengan baik diseluruh platform pada berbagai jenis smartphone.

\section{DAFTAR PUSTAKA}

Abidin, M. M., Purnama, B. E., \& Nugroho, G. K. (2013). Pembangunan media pembelajaran teknik komputer jaringan kelas X semster ganjil pada Sekolah Menengah Kejuruan Taruna Bangsa Pati berbasis multimedia interaktif. IJNS-Indonesian Journal on Networking and Security, 4(3), 1-6. doi: http://dx.doi.org/10.1123/ijns.v4i3.295

Adiwisastra, M. F. (2015). Perancangan game kuis interaktif sebagai multimedia pembelajaran drill and practice untuk meningkatkan hasil belajar siswa. Jurnal Informatika, 2(1), 205-211. doi: https://doi.org/10.31294/ji.v2i1.67

Alwan, M. (2017). Pengembangan model blended learning menggunakan aplikasi Edmodo untuk mata pelajaran geografi SMA. Jurnal Inovasi Teknologi Pendidikan, 4(1), 65-76. doi: https://doi.org/10.21831/jitp.v4i1.10505

Ambiyar, A., \& Arif, A. (2018). Evaluasi dengan discrepancy model pada proses pembelajaran memperbaiki sistem starter dan sistem pengisian di SMK N 2 Sijunjung. Jurnal Pendidikan Teknologi dan Kejuruan: Research and Learning in Vocational Education, 1(1), 25-30. 
116 - Jurnal Inovasi Teknologi Pendidikan

Retrieved from http://repository.unp.ac.id/16066/1/5.\%20Ambiyar\%2C\%20Asril\%20Arif.pdf

Amin, A. K. (2017). Kajian konseptual model pembelajaran blended learning berbasis web untuk meningkatkan hasil belajar dan motivasi belajar. Jurnal Pendidikan Edutama, 4(2), 51-64. doi: http://dx.doi.org/10.30734/jpe.v4i2.55

Anisya, A., \& Swara, G. Y. (2020). Aplikasi e-management project. Jurnal Teknoif Teknik Informatika Institut Teknologi Padang, 8(1), 39-46. doi: http://dx.doi.org/10.21063\%2Fjtif.2020.V8.1.39-46

Arifin, F., \& Herman, T. (2018). Pengaruh pembelajaran e-learning model web centric course terhadap pemahaman konsep dan kemandirian belajar matematika siswa. Jurnal Pendidikan Matematika, 12(2), 1-12. doi: https://doi.org/10.22342/jpm.12.2.4152.1-12

Batubara, H. H. (2018). Pengembangan media pembelajaran matematika berbasis android untuk siswa SD/MI. Muallimuna: Jurnal Madrasah Ibtidaiyah, 3(1), 12-27. doi: http://dx.doi.org/10.31602/muallimuna.v3i1.952

Degeng, I. N. S. (2013). Ilmu pembelajaran: Klasifikasi variabel untuk pengembangan teori dan penelitian. Bandung: Kalam Hidup.

Firdaus, S., \& Hamdu, G. (2020). Pengembangan mobile learning video pembelajaran berbasis STEM (Science, Technology, Engineering And Mathematics) di sekolah dasar. JINOTEP (Jurnal Inovasi dan Teknologi Pembelajaran) : Kajian dan Riset Dalam Teknologi Pembelajaran, 7(2), 66-75. doi: http://dx.doi.org/10.17977/um031v7i22020p066

Koesnandar, A. (2019). Pengembangan software pembelajaran multimedia interaktif. Jurnal Teknodik, 10(18), 75-88. doi: http://dx.doi.org/10.32550/teknodik.v0i0.548

Kramer, M. (2018). Best practices in systems development lifecycle: An analyses based on the waterfall model. Review of Business \& Finance Studies, 9(1), 77-84. Retrieved from https://poseidon01.ssrn.com/delivery.php?ID $=149097083081121111112093110120114091$ 1040140590820600180710010800231170231181190110641171190510590210510110871 0401111300008802502007001105101502701100307502810410301006207805208600709 6102123087022094088115067120108006103011118014015064114121124121094087\&E XT=pdf\&INDEX $=$ TRUE

Liana, L. (2009). Penggunaan MRA dengan SPSS untuk menguji pengaruh variabel moderating terhadap hubungan antara variabel independen dan variabel dependen. Dinamik, 14(2), 9097. Retrieved from https://www.unisbank.ac.id/ojs/index.php/fti1/article/view/95

Lidinillah, D. A. M. (2008). Strategi pembelajaran pemecahan masalah di sekolah dasar. Jurnal Pendidikan Dasar, 10, 1-5. Retrieved from http://file.upi.edu/Direktori/KDTASIKMALAYA/DINDIN_ABDUL_MUIZ_LIDINILLAH_(KD-TASIKMALAYA)$197901132005011003 / 132313548 \% 20$ \%20dindin\%20abdul\%20muiz\%20lidinillah/Pembelajaran\%20Problem\%20Solving\%20di \%20SD.pdf

Maskur, R., Nofrizal, N., \& Syazali, M. (2017). Pengembangan media pembelajaran matematika dengan Macromedia Flash. Al-Jabar: Jurnal Pendidikan Matematika, 8(2), 177-186. doi: https://doi.org/10.24042/ajpm.v8i2.2014

Marfalino, H., Guslendra, G., \& Sari, A. M. (2017). Implementasi sistem informasi akuntansi pada Koperasi Anggrek II Jorong Pandan Kecamatan Tanjung Raya Kabupaten Agam didukung dengan menerapkan aplikasi sistem multiuser pada bahasa pemrograman Java dan Database MySQL. JTIP: Jurnal Teknologi Informasi dan Pendidikan, 10(2), 59-72. doi: https://doi.org/10.24036/tip.v10i2.32

Marnita, M., Taufiq, M., Iskandar, I., \& Rahmi, R. (2020). The effect of blended learning problembased instruction model on students' critical thinking ability in thermodynamic course.

Volume 7, No. 2, Oktober 2020 


$$
\begin{array}{r}
\text { Pengembangan multimedia pembelajaran matematika ... } \\
\text { Ganda Yoga Swara, Ambiyar Ambiyar, Fadhilah Fadhilah, Syahril Syahril }
\end{array}
$$

Jurnal Pendidikan IPA Indonesia, 9(3), 430-438. doi: https://doi.org/10.15294/jpii.v9i3.23144

Nasution, M. I. P. (2016). Strategi pembelajaran efektif berbasis mobile learning pada sekolah dasar. IQRA': Jurnal Perpustakaan dan Informasi, 10(1), 1-14. Retrieved from https://www.researchgate.net/profile/Muhammad Irwan_Nasution/publication/305207211 STRATEGI PEMBELAJARAN EFEKTIF BERBASIS MOBILE LEARNING PADA SEKOLAH DASAR/links/5784a40e08aee45b84445c13/STRATEGIPEMBELAJARAN-EFEKTIF-BERBASIS-MOBILE-LEARNING-PADA-SEKOLAHDASAR.pdf

Prihandoyo, M. T. (2018). Unified Modeling Language (UML) model untuk pengembangan sistem informasi akademik berbasis web. Jurnal Informatika: Jurnal Pengembangan IT, 3(1), 126129. doi: http://dx.doi.org/10.30591/jpit.v3i1.765

Purnamasari, S., \& Herman, T. (2016). Penggunaan multimedia interaktif terhadap peningkatan kemampuan pemahaman dan komunikasi matematis, serta kemandirian belajar siswa sekolah dasar. EduHumaniora: Jurnal Pendidikan Dasar, 8(2), 178-185. doi: https://doi.org/10.17509/eh.v8i2.5140

Saputra, J. (2015). Penggunaan model problem based learning berbantuan e-learning dalam upaya meningkatkan kemampuan pemecahan masalah matematis dan dampaknya terhadap kemandirian belajar mahasiswa (Unpublished doctoral dissertation). Universitas Pasundan Bandung, Indonesia.

Sasmito, G. W. (2017). Penerapan metode waterfall pada desain sistem informasi geografis industri Kabupaten Tegal. Jurnal Informatika: Jurnal Pengembangan IT, 2(1), 6-12. doi: http://dx.doi.org/10.30591/jpit.v2i1.435

Setyadi, D. (2017). Pengembangan mobile learning berbasis android sebagai sarana berlatih mengerjakan soal matematika. Satya Widya, 33(2), 87-92. doi: https://doi.org/10.24246/j.sw.2017.v33.i2.p87-92

Sujarweni, V. W., \& Utami, L. R. (2019). The master book of SPSS. Anak Hebat Indonesia.

Surahman, E., \& Surjono, H. D. (2017). Pengembangan adaptive mobile learning pada mata pelajaran biologi SMA sebagai upaya mendukung proses blended learning. Jurnal Inovasi Teknologi Pendidikan, 4(1), 26-37. doi: https://doi.org/10.21831/jitp.v4i1.9723

Swara, G. Y. (2020). Pemanfaatan visualisasi 3D pada multimedia interaktif dalam pengenalan penyakit demam berdarah. Jurnal TeknoIf, 8(1), 19-24. doi: http://dx.doi.org/10.21063\%2Fjtif.2020.V8.1.19-24

Wahyuningsih, D., \& Budiningsih, C. A. (2014). Implementasi Blended Learning by the Constructive Approach (BLCA) dalam pembelajaran interaksi manusia dan komputer. Jurnal Inovasi Teknologi Pendidikan, 1(1), 15-27. doi: https://doi.org/10.21831/tp.v1i1.2456

Wibawanto, W. (2017). Desain dan pemrograman multimedia pembelajaran interaktif. Jember: Cerdas Ulet Kreatif.

Wibowo, E. J. (2013). Media pembelajaran interaktif matematika untuk siswa sekolah dasar kelas IV. Seminar Riset Unggulan Nasional Informatika dan Komputer, 2(1), 75-78. doi: http://dx.doi.org/10.0809/seruni.v2i1.584

Wulandari, R., Susilo, H., \& Kuswandi, D. (2017). Penggunaan multimedia interaktif bermuatan game edukasi untuk meningkatkan aktivitas dan hasil belajar siswa sekolah dasar. Jurnal Pendidikan: Teori, Penelitian, dan Pengembangan, 2(8), 1024-1029. doi: http://dx.doi.org/10.17977/jptpp.v2i8.9759 